Original Article

\title{
High and ultra low concentrations of Mercuric chloride initiate their specific action on binding sites of invertase and modify its interaction with sucrose
}

\author{
Atheni Konar, M.Sc. ${ }^{1,2}$, Tandra Sarkar, M.Sc.1,2, Nirmal Chandra Sukul, Ph.D. ${ }^{2,3}$, Anirban Sukul*, \\ Ph.D², Indrani Chakraborty, Ph.D ${ }^{4}$, Sriparna Ray, M.Sc. ${ }^{5}$ \\ ${ }^{1}$ Centre for Healthcare Science \& Technology, Indian Institute of Engineering, Science \& Technology, \\ Shibpur, Howrah, West Bengal-711103, India. \\ 2Sukul Institute of Homeopathic Research, Santiniketan -731235, West Bengal, India. \\ ${ }^{3}$ Department of Zoology, Visva-Bharati University, Santiniketan-731235, West Bengal, India. \\ ${ }^{4}$ Department of Zoology, Belda College, West Bengal, India. \\ 5Department of Zoology, Bidhan Chandra College, Asansol-713305, West Bengal, India. \\ *Correspondence author: N.C.Sukul (e-mail: ncsukul@gmail.com)
}

\begin{abstract}
Background: Mercuric chloride is known to inhibit the activity of enzymes. It is used in homeopathy at ultra low concentration (ULC) and is known as Mercurius corrosivus (Merc cor). ULCs of Merc cor are reported to promote enzyme activity. Objective: To see whether the mother tincture $(\theta)$ of $\operatorname{Merc}$ cor and its ULCs interact with an enzyme invertase at its binding sites and influence enzyme's action on its substrate sucrose. Methods: $\operatorname{Merc} \operatorname{cor} \theta\left(0.15 \mathrm{M} \mathrm{HgCl}_{2}\right)$ was diluted with deionized and distilled (DD) water 1:100 and succussed 10 times to prepare Merc cor $1 \mathrm{cH}$ or $1^{\text {st }}$ potency. This potency was further diluted and succussed in 200 and 1000 steps to prepare $200 \mathrm{cH}$ and $1000 \mathrm{cH}$ potencies, respectively. Merc cor $200 \mathrm{cH}$ and 1000cH were prepared in $90 \%$ ethanol. The two potencies and blank $90 \%$ EtOH were diluted with DD water 1:1000 to minimize ethanol content to a negligible amount $0.09 \%$. The control was DD water $(0.99 \mathrm{~g} / \mathrm{M})$. The drugs, EtOH and water control were mixed separately with $0.037 \mathrm{mM}$ invertase in DD water. Using an isothermal calorimetry (ITC) instrument the substrate sucrose $(65 \mathrm{mM})$ was injected at $2 \mu$ l every 2 min into $300 \mu$ invertase solution 20 times at $25{ }^{\circ} \mathrm{C}$. Molecular modeling study was done to predict possible binding sites and nature of binding between the enzyme and $\mathrm{HgCl}_{2}$, and between the enzyme and water. Potencies after dilution are virtually water. Fluorescence spectra of invertase $(4 \mu \mathrm{M})$ mixed with drug/control solutions were also obtained to see the effect of drugs on protein folding. Results: Thermodynamic parameters like binding constant $(\mathrm{K})$, change in enthalpy $(\Delta \mathrm{H})$, entropy $(\Delta \mathrm{S})$ and Gibbs free energy $(\Delta \mathrm{G})$ showed marked variation in treatment effects on the enzyme. Molecular modeling study also shows variation in binding between invertase and $\mathrm{HgCl}_{2}$, and between invertase and water. Fluorescence spectra show variation in quenching related to different treatments. Conclusion: Merc cor mother tincture and its potencies interact at different binding sites of invertase and modify the enzyme's action on sucrose. So, potencies act as modulators of ligand, sucrose. Drug solutions induce conformational changes in the enzyme.
\end{abstract}

Keywords: Invertase, binding site, mercuric chloride, ultra low concentration, molecular modeling

\section{Introduction}

Ultra low concentrations (ULC) of drugs, which very often cross the Avogadro number, have been used in homeopathy for more than a couple of centuries [1-2]. Using vibrational and Raman 
spectroscopy as well as differential scanning calorimetry (DSC) it was shown that the physical basis of ULCs consists of two factors: free water molecules or $\mathrm{OH}$ groups and hydrogen bond strength of the $\mathrm{OH}$ groups [3-7]. The question remains as to how the free water molecules instead of original drug molecules in ULCs could initiate their action on a patient. Since ULCs are usually administered through the oral route it is possible that some proteins, may be membrane ones, can be the first target. Using isothermal calorimetry (ITC), we recently demonstrated that both high concentration (HC) and ULC of two drugs mercuric chloride and sodium chloride bind to specific binding sites of $\alpha$ amylase and bovine serum albumin (BSA), respectively [8-9]. Mercuric chloride is a known inhibitor of enzymes including $\alpha$-amylase and invertase. It is also a homeopathic drug Mercurius corrosives (Merc cor) and used in the form of ULCs, which are prepared by successive dilution 1:100 followed by succussion or mechanical agitation in several steps. Depending on the number of steps used for preparation of ULC, it is given a rank called potency like $30 \mathrm{cH}, 200 \mathrm{cH}, 1000 \mathrm{cH}$ etc. [10]. It was demonstrated that potentized Mercuric chloride promoted the activity of another enzyme $\alpha$-amylase [11-12].

The objective of the present study is to see whether Merc $\operatorname{cor} \theta$ and its potencies could bind to specific binding sites of invertase and influence the interaction between the enzyme and its substrate sucrose. Thermodynamic parameters of this interaction were measured by ITC. The effect of Merc cor $\theta$ and potencies on invertase were further studied by fluorescence spectroscopy. In order to examine the possible nature of binding sites between the enzyme and $\operatorname{Merc} \operatorname{cor} \theta$, and also between the enzyme and water we made molecular modelling study.

\section{Materials and Methods}

Invertase and sucrose were obtained from Sigma chemical Co, USA. The enzyme activity has been mentioned as 100 units/mg. Mercuric chloride $\left(\mathrm{HgCl}_{2}\right)$ was obtained from E. Merck, Germany. It was dissolved in deionized distilled (DD) water to make $147 \mathrm{mM}$ solution. This is designated as Merc cor mother tincture ( $\theta$ ). Merc cor $200 \mathrm{cH}$ and $1000 \mathrm{cH}$ in $90 \%$ ethanol were produced in the laboratory following Korsakovian method [10,13]. The succussion machine was designed in the laboratory. The mechanical arm, $40 \mathrm{~cm}$ long, has a $400 \mathrm{~g}$ iron cage at the tip holding a $30 \mathrm{ml}$ vial. The vial is filled $2 / 3$ rd with the drug in aqueous ethanol (90\%). Ten succussions/30sec are given for each rank of a potency. The diluent medium ( $90 \%$ ethanol) obtained from E. Merck, Germany, was not potentized. It may be mentioned here that alcohol is not a mere vehicle but itself a homeopathic drug ${ }^{[14]}$. Merc cor $200 \mathrm{cH}, 1000 \mathrm{cH}$ and ethanol were diluted with DD water $1: 1000$ just before the experiment in order to minimize the ethanol content in the samples but retaining the drug effect ${ }^{[15]}$. Using a UVVIS spectrophotometer (Shimadzu, model UV-2401 PC) optical density (OD) of drug and ethanol solutions was measured at $220.5 \mathrm{~nm}$ and found to be same.

Calorimetric measurements were made by ITC 200, GE Healthcare, Biosciences Ltd, Sweden. Reaction cells $(0.2 \mathrm{ml})$ were filled with degassed solutions and equilibrated at the indicated temperature. Stirring speed was $400 \mathrm{rpm}$ and thermal power was recorded every $2 \mathrm{~s}$. Both the sample and reference cells containing solvent only were maintained at a constant temperature of $25^{\circ} \mathrm{C}$. Once the thermal equilibrium was reached, injections of the substrate solution ( $65 \mathrm{mM}$ sucrose) into $300 \mu \mathrm{l}$ of $0.037 \mathrm{mM}$ invertase were started. Twenty injections, one every $2 \mathrm{~min}$, were given at the rate of $2 \mu \mathrm{l}$ sucrose solution per injection. The drugs, ethanol or water control was mixed separately with $0.037 \mathrm{mM}$ invertase in the proportion of $1: 10$. Invertase and sucrose solutions were prepared in DD water. We used one sample for each experiment as usual with ITC experiments. ITC provides accurate data on binding interaction between a protein, here invertase and a ligand, here sucrose in a single 
experiment with one sample under optimal conditions [16]. Thermodynamic parameters like $\Delta \mathrm{H}$ and $\Delta \mathrm{S}$ can be calculated by using Eryng's plot [17]. In our case the values were automatically calculated by a built-in software in the ITC instrument.

Molecular modeling

In the present study we used $\mathrm{HgCl}_{2}$ and its ULCs. The ULCs are virtually water without any original drug molecules, but this water is structurally different from ordinary water. In order to predict possible binding site and the nature of interaction between the drug solutions and invertase, the complementary application of molecule docking was made using Molecular Docking Server. The amino acid sequence of invertase was retrieved from Protein Bank Data Server [18].

\section{Fluorescence Spectroscopy}

Fluorescence emission spectra of invertase in presence of water, alcohol, Merc cor 200, Merc cor $1 \mathrm{M}$, and Merc $\operatorname{cor} \theta$ were recorded separately using a spectrofluorimeter (Jasco, model: FP-8500, Japan) having a $1.0 \mathrm{~cm}$ optical path length. The excitation wave length was $280 \mathrm{~nm}$, and emission spectra were recorded in the range of 300-400 $\mathrm{nm}$. The excitation and emissions band widths were $5 \mathrm{~nm}$ and $10 \mathrm{~nm}$, respectively. The concentration of invertase was $4 \mu \mathrm{M}$. It was mixed with drug/control solution in the propotion of 10:1. The drug and ethanol solutions were originally in $90 \%$ ethanol which was diluted with DD water 1:1000. Thus the ethanol content in all the drug solutions was same (0.09\%). Mercuric chloride was dissolved in DD water and its concentration was $147 \mathrm{mM}$. One sample was taken for each experiment just to show difference in intensity in invertase due to different potencies. For this no relative difference from each other can be expressed.

\section{Results}

ITC Experiment

Ethanol content in drug or blank ethanol solutions (1:1000), is negligible (0.09\%). Results of the ITC experiments are presented in Figures 1-5 and Table 1. Each figure contains two panels A and B. Panel A shows heat rate $(\mu \mathrm{cal} / \mathrm{sec}$ ) versus time in min. Each peak represents an injection of ligand $(65 \mathrm{mM}$ sucrose solution) into the sample cell containing the $0.037 \mathrm{mM}$ invertase mixed with control or drug solution. Panel B shows heat released per mole of ligand during interaction with invertase in relation to molar ratio, ligand/invertase in the form of non-linear regression. Here the best fit parameters like binding constant $(\mathrm{K})$, change in enthalpy $(\Delta \mathrm{H})$, change in entropy $(\Delta \mathrm{S})$ and the number of binding sites for complex formation are recorded. Gibbs free energy change $(\Delta \mathrm{G})$ is calculated from $\Delta \mathrm{H}$, $\Delta \mathrm{S}$ and $\mathrm{T}$ (absolute temperature in Kelvin): $\Delta \mathrm{G}=\Delta \mathrm{H}-\mathrm{T} \Delta \mathrm{S}$. All these parameters for each sample are given in Table1. Figure 1A,B stands for invertase + water control $(0.99 \mathrm{~g} / \mathrm{M})$, Figure 2 A,B for invertase + ethanol, Figure $3 \mathrm{~A}, \mathrm{~B}$ for invertase $+\mathrm{HgCl}_{2}$, Figure 4 for invertase + Merc cor 1000 $\mathrm{cH}$ and Figure 5 for invertase + Merc cor $200 \mathrm{cH}$. 


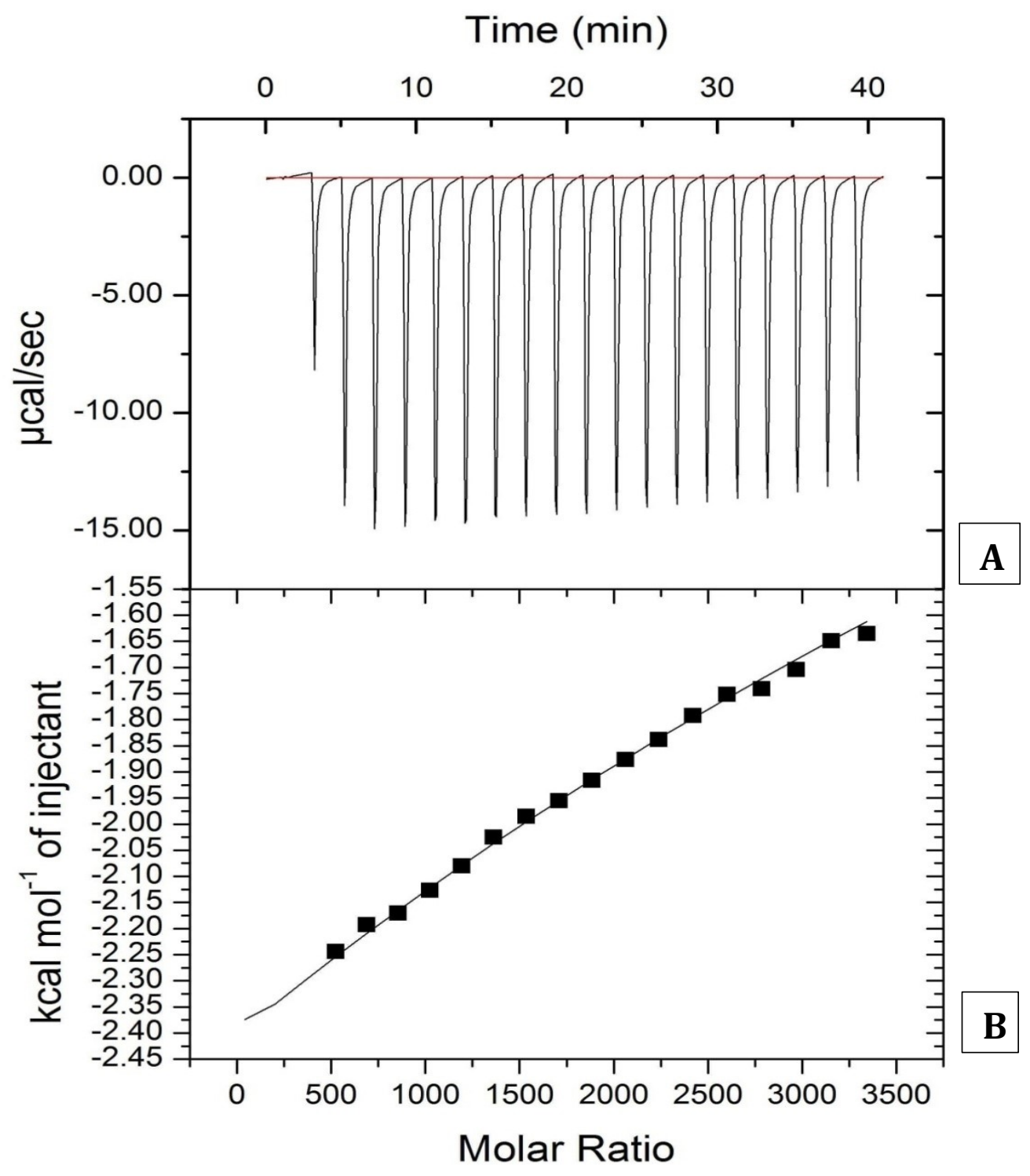

Figure 1. A: Heat rate vs time titration curve. Each peak represents an injection of ligand $(65 \mathrm{mM}$ sucrose solution in water) into sample cell containing $0.037 \mathrm{mM}$ invertase in water mixed with water $(10: 1)$ at $25^{\circ} \mathrm{C}$.

B: Non-linear regression showing heat released per mole of ligand during interaction with invertase in relation to molar ratio, ligand/invertase. Exothermic reaction. ITC parameters in Table 1. 


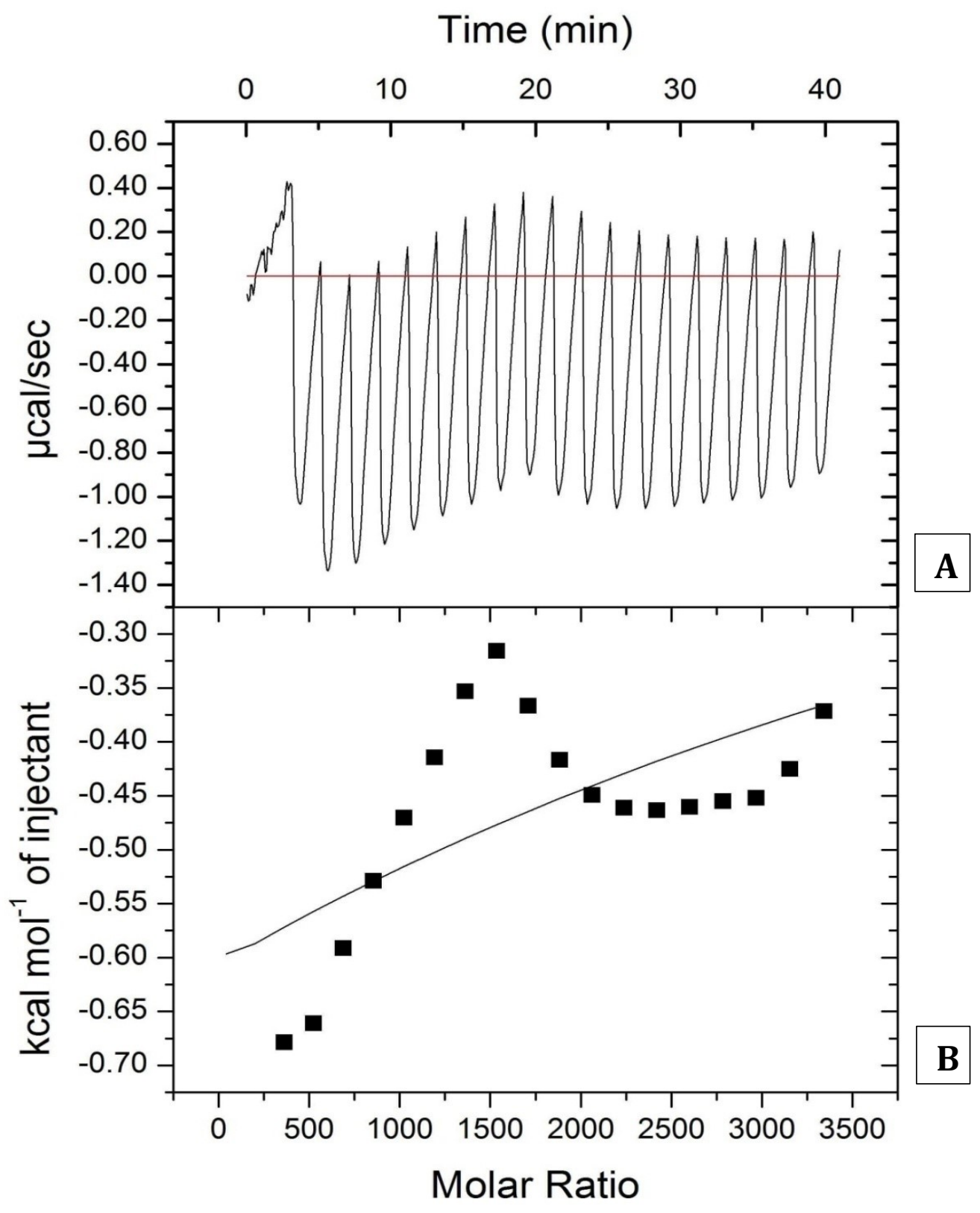

Figure 2. A: Heat rate vs time titration curve. Each peak represents an injection of ligand $(65 \mathrm{mM}$ sucrose solution in water) into sample cell containing $0.037 \mathrm{mM}$ invertase in water mixed with $0.09 \%$ ethanol (10:1) at $25^{\circ} \mathrm{C}$.

B: Non-linear regression showing heat released per mole of ligand during interaction with invertase in relation to molar ratio, ligand/invertase. Exothermic reaction. ITC parameters in Table 1. 


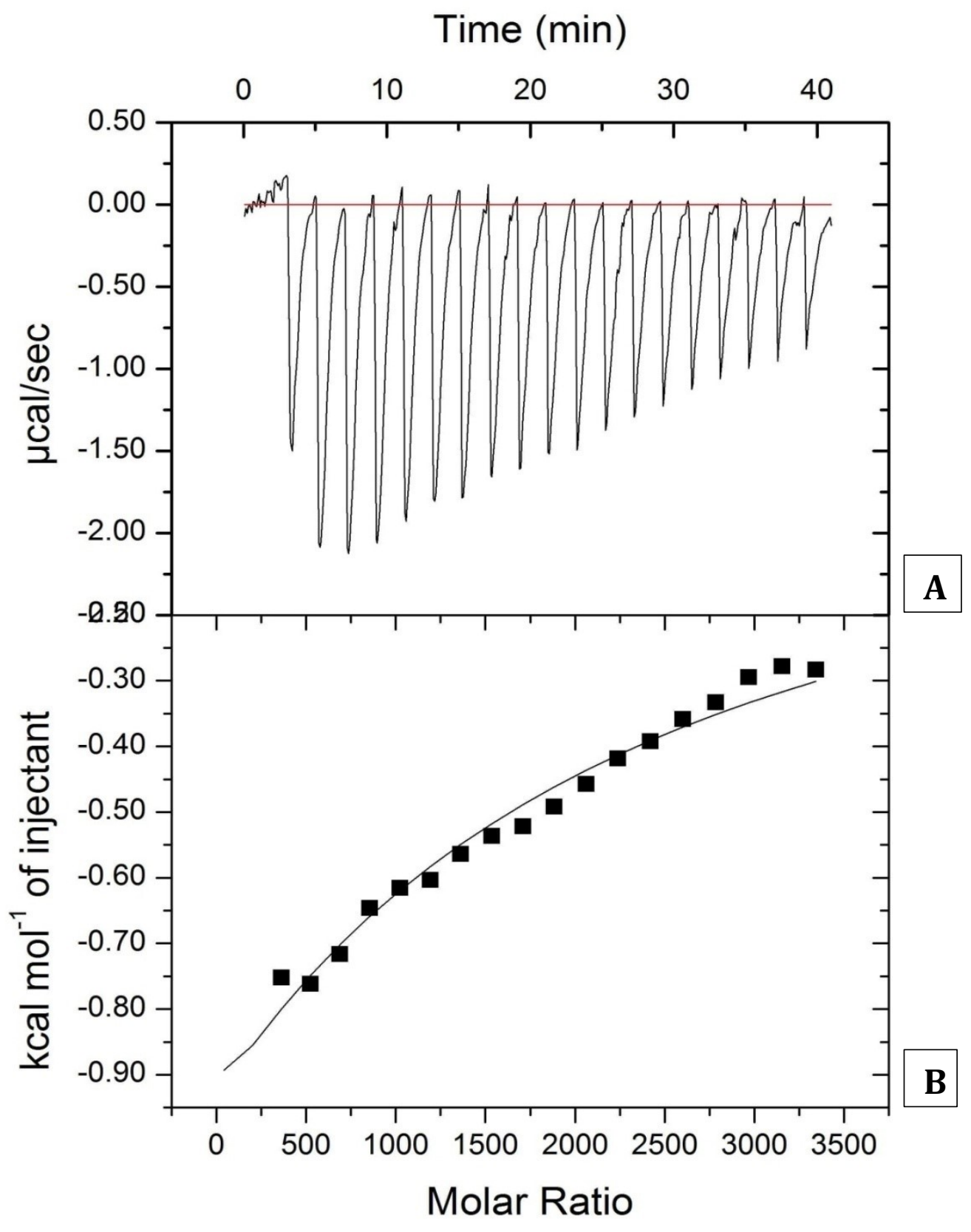

Figure 3. A: Heat rate vs time titration curve. Each peak represents an injection of ligand $(65 \mathrm{mM}$ sucrose solution in water) into sample cell containing $0.037 \mathrm{mM}$ invertase in water mixed with $147 \mathrm{mM} \mathrm{HgCl}_{2}$ solution in water $(10: 1)$ at $25^{\circ} \mathrm{C}$.

B: Non-linear regression showing heat released per mole of ligand during interaction with invertase in relation to molar ratio, ligand/invertase. Exothermic reaction. ITC parameters in Table1. 


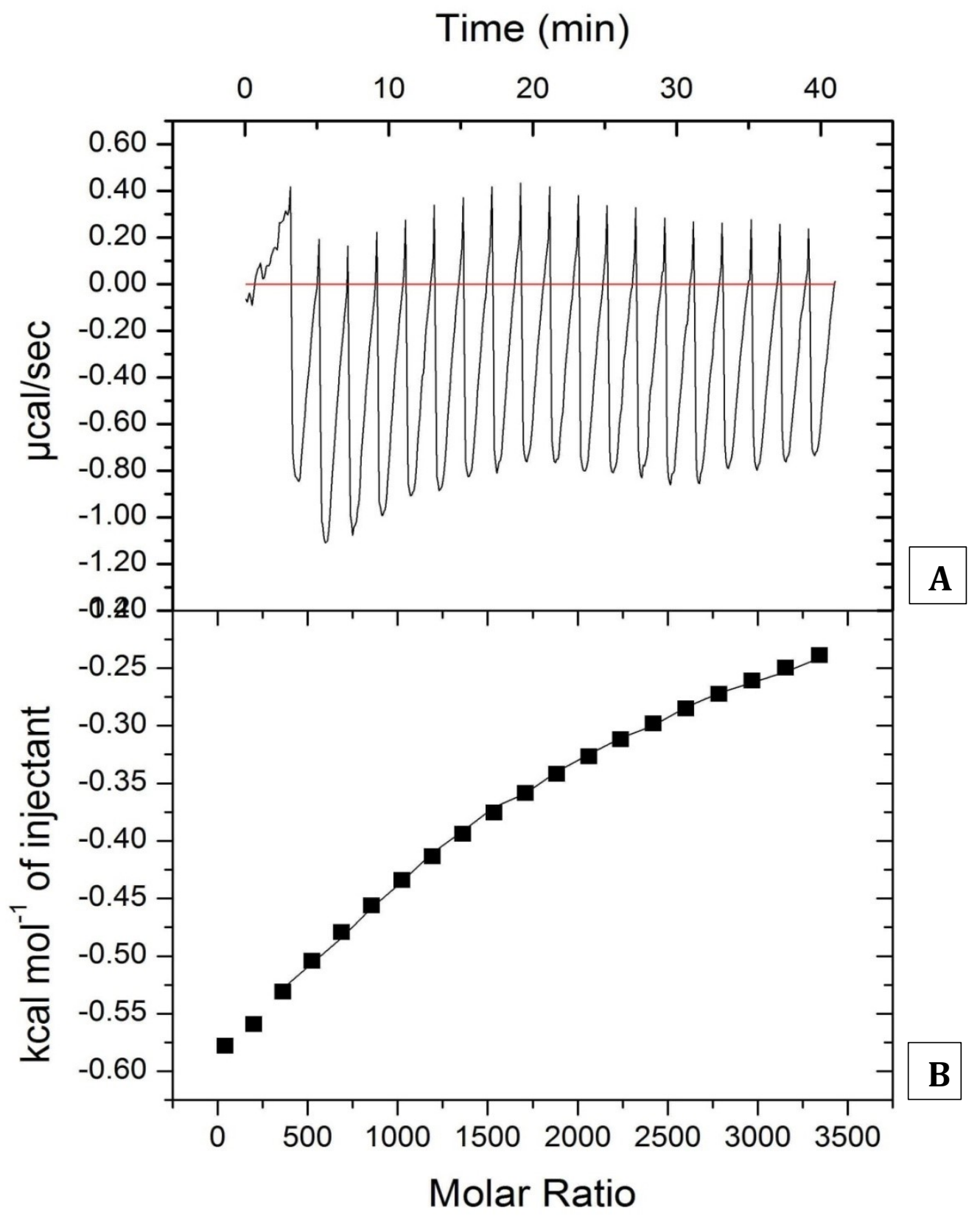

Figure 4. A: Heat rate vs time titration curve. Each peak represents an injection of ligand $(65 \mathrm{mM}$ sucrose solution in water) into sample cell containing $0.037 \mathrm{mM}$ invertase in water mixed with Merc cor $1 \mathrm{M}$ in $0.09 \%$ EtOH $(10: 1)$ at $25^{\circ} \mathrm{C}$.

B: Non-linear regression showing heat released per mole of ligand during interaction with invertase in relation to molar ratio, ligand/invertase. Exothermic reaction. ITC parameters in Table 1. 


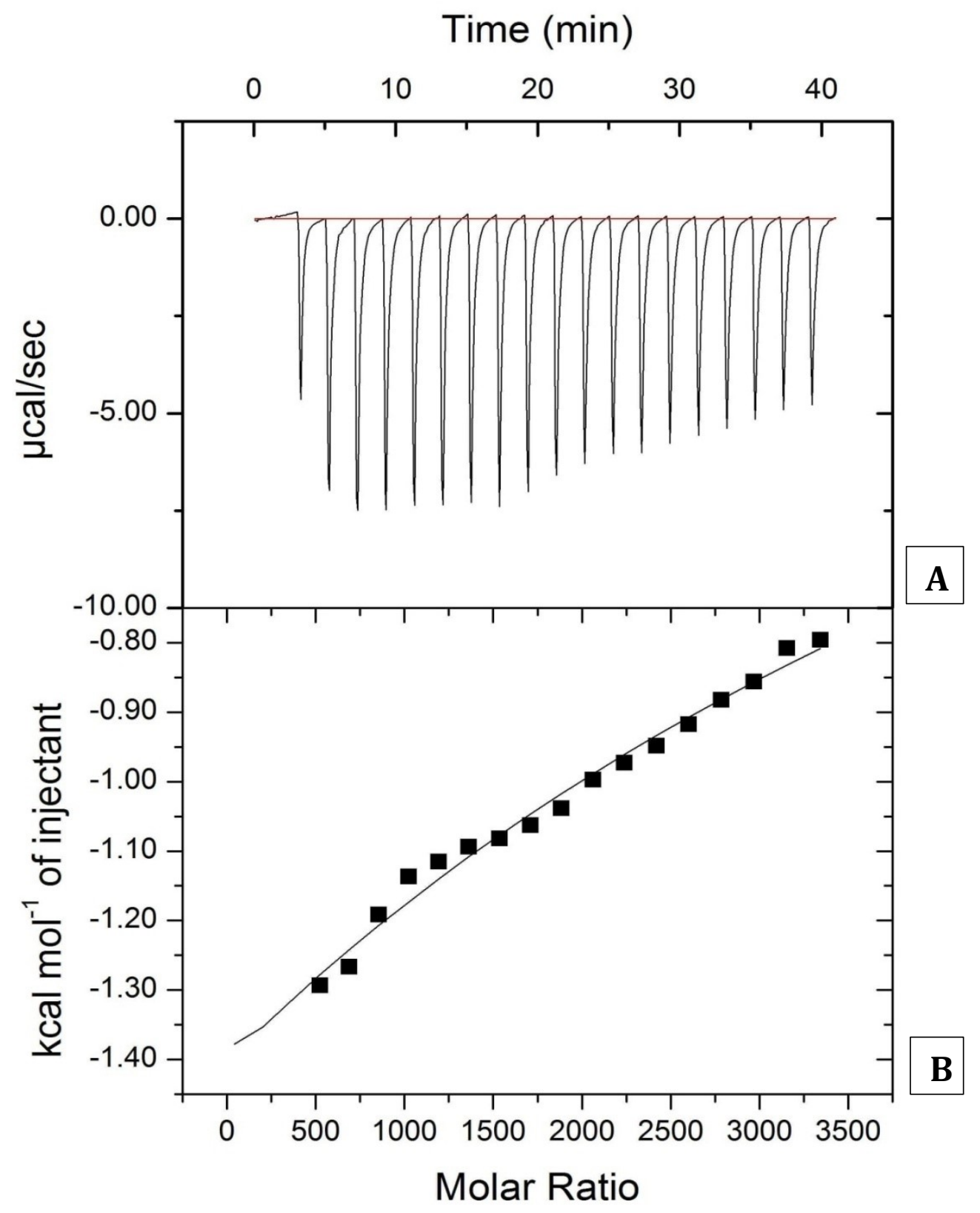

Figure 5: A: Heat rate vs time titration curve. Each peak represents an injection of ligand $(65 \mathrm{mM}$ sucrose solution in water) into sample cell containing $0.037 \mathrm{mM}$ invertase in water mixed with Merc cor $200 \mathrm{cH}$ in $0.09 \% \mathrm{EtOH}(10: 1)$ at $25^{\circ} \mathrm{C}$.

B: Non-linear regression showing heat released per mole of ligand during interaction with invertase in relation to molar ratio, ligand/invertase. Exothermic reaction. ITC parameters in Table 1. 
An analysis of ITC data by an inbuilt software origin 7 indicates single site binding and exothermic reaction for all the samples studied (Table 1). Table 1 shows marked variation in thermodynamic parameters in between all the samples. However, $\Delta \mathrm{H}, \Delta \mathrm{S}$, and $\Delta \mathrm{G}$ values show similar pattern of variation with respect to all the drugs/control studied. Viewed from this perspective drugs/control can be ranked as follows: water $>$ Merc cor $200 \mathrm{cH}>$ Ethanol $>$ Merc $\operatorname{cor} 1 \mathrm{M}>$ Merc $\operatorname{cor} \theta$. But the K values show a different pattern: Merc $\operatorname{cor} \theta>$ Merc $\operatorname{cor} 200>$ Merc $\operatorname{cor} 1 \mathrm{M}>$ Ethanol $>$ Water (Table 1).

\begin{tabular}{|c|c|c|c|c|c|}
\hline $\begin{array}{l}\text { Drugs/Control } \\
\text { mixed with } \\
\text { invertase } \\
(1: 10)\end{array}$ & $\begin{array}{l}K_{M}^{-1} \\
\text { (Binding } \\
\text { constant } \\
\text { ) }\end{array}$ & $\begin{array}{c}\Delta \mathrm{H} \\
\mathrm{Cal} / \mathrm{mol} \\
\times 10^{6}\end{array}$ & $\begin{array}{c}\Delta S \\
\mathrm{Cal} / \mathrm{mol} / \mathrm{d} \\
\mathrm{eg} \\
\times 10^{4} \\
\end{array}$ & $\begin{array}{c}\Delta \mathrm{G} \\
\mathrm{Cal} / \mathrm{mol} \\
\times 10^{6}\end{array}$ & $\begin{array}{l}\text { No. of binding sites, } \\
\text { reaction }\end{array}$ \\
\hline $\begin{array}{c}\text { Water } \\
\text { (Control) } \\
55 \mathrm{mM}\end{array}$ & 0.133 & $-1.84 \times 10^{5}$ & $-6.19 \times 10^{4}$ & $-1.68 \times 10^{5}$ & $\begin{array}{l}1, \quad \text { Exothermic,heat } \\
\text { change } \\
\text { largest, } 15 \mu \mathrm{cal} / \mathrm{sec} \text {,satu } \\
\text { ration not reached }\end{array}$ \\
\hline $\begin{array}{c}\text { Ethanol } \\
4 \mu \mathrm{m}\end{array}$ & 4.96 & $-3.01 \times 10$ & $-1.01 \times 10$ & $-2.76 \times 10$ & $\begin{array}{l}1, \quad \text { Exothermic heat } \\
\text { change moderate, } 1.30 \\
\mu \mathrm{cal} / \mathrm{sec}\end{array}$ \\
\hline $\begin{array}{l}\text { Merc cor } \theta \\
147 \mathrm{mM}\end{array}$ & 39.2 & -5.74 & -1.93 & -5.25 & $\begin{array}{l}\text { 1, Exothermic,heat } \\
\text { change profound more } \\
\text { than } 2 \mu \mathrm{cal} / \mathrm{sec}, \text { tending } \\
\text { to gradual saturation }\end{array}$ \\
\hline $\begin{array}{c}\text { Merc cor } 200 \\
\text { cH } \\
100 \mu \mathrm{M}\end{array}$ & 7.14 & $-4.84 \times 10$ & $-1.62 \times 10$ & $-4.40 \times 10$ & $\begin{array}{l}\text { 1,Exothermic, Profound } \\
\text { binding, heat change } \\
\text { large } \\
5.50 \mu \mathrm{cal} / \mathrm{sec} \text {,tending to } \\
\text { gradual saturation }\end{array}$ \\
\hline $\begin{array}{l}\text { Merc cor 1M } \\
100 \mu \mathrm{M}\end{array}$ & 5.05 & -7.18 & -2.41 & -6.60 & $\begin{array}{l}1, \quad \text { Exothermic,heat } \\
\text { change moderate } \\
1.1 \mu \mathrm{cal} / \mathrm{sec} \text {,saturation } \\
\text { very slow }\end{array}$ \\
\hline
\end{tabular}

Table 1: Thermodynamic parameters of interaction between $0.037 \mathrm{mM}$ invertase and $65 \mathrm{mM}$ sucrose at $25^{\circ} \mathrm{C}$. Invertase in water was mixed with a drug solution or water control in the proportion of 10:1 and kept in the sample cell. The substrate sucrose was injected into invertase 20 times at $2 \mu \mathrm{l} /$ injection every $2 \mathrm{~min}$. Change in enthalpy $(\Delta \mathrm{H})$, entropy $(\Delta \mathrm{S})$, free energy $(\Delta \mathrm{G})$. Stoichiometry 1 with all the test samples.

\section{Molecular Modelling}

Figure 6 shows an overview of the binding of mercuric chloride with invertase. Green coloured structures represent the drug molecules, the red ones oxygen, the blue ones hydrogen and the yellow 
ones carbon. Different amino acids involved in binding are shown with their respective position. Ribbons represent interacting side chains of amino acid residues. The blue coloured benzene ring represents an amino acid. Figure 7 illustrates the binding of invertase with water molecules. Here also red color stands for oxygen and yellow for carbon.

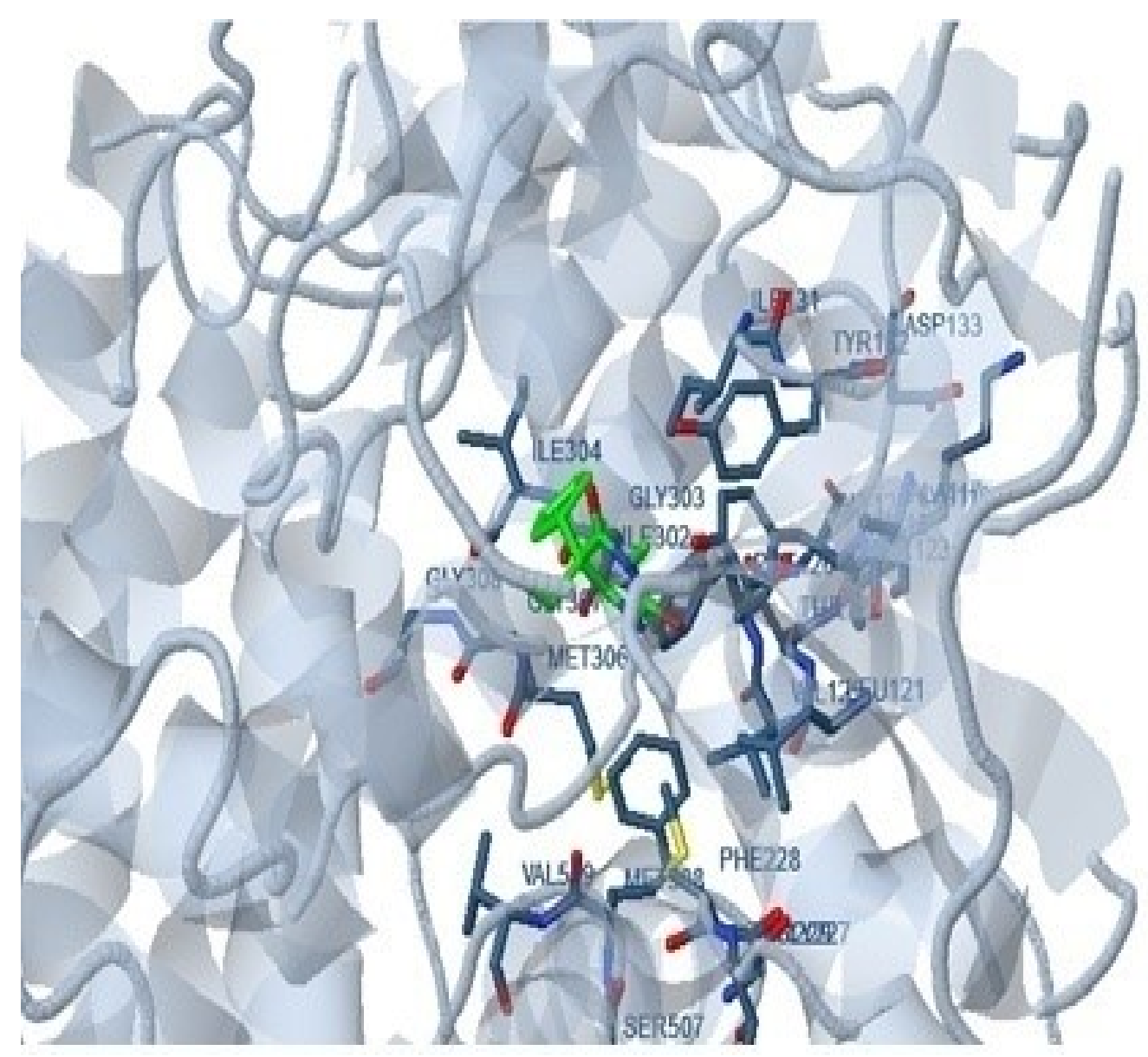

Figure 6. Schematic representation of invertase-mercuric chloride complexes showing the close amino acid residues involved in binding with mercuric chloride molecules. Location of amino acid residues have also been indicated.

Blue colored benzene rings represent amino acids. Amino acids involved in binding are also shown in the figure. Ribbons represent interacting side chains of amino acids. Amino acid residues of invertase involved in binding interaction with mercuric chloride are TYR 132 showing polar interaction and TYR 118 showing hydrophobic interaction. In case of binding with water amino acids like SER 226 and ASN 238 show polar interaction. Differences in energy of binding between invertase and water, and between invertase and mercuric chloride, as revealed by Molecular Modelling, are shown in Table 2. Besides inhibition constant all other values are higher with mercuric chloride than with water (Table 2). 


\begin{tabular}{|c|c|c|c|c|c|c|}
\hline Samples & $\begin{array}{c}\text { Est.free } \\
\text { energy of } \\
\text { binding }\end{array}$ & $\begin{array}{c}\text { Est.inhibition } \\
\text { constant, } \mathrm{k} !\end{array}$ & $\begin{array}{c}\mathrm{vdW}+\mathrm{H} \\
\text { bond+desolv } \\
\text { energy }\end{array}$ & $\begin{array}{c}\text { Electrostatic } \\
\text { Energy }\end{array}$ & $\begin{array}{c}\text { Total } \\
\text { intermolec. } \\
\text { Energy }\end{array}$ & $\begin{array}{c}\text { Interact } \\
\text { surface }\end{array}$ \\
\hline Invertase+water & $\begin{array}{c}-1.42 \\
\mathrm{Kcal} / \mathrm{mol}\end{array}$ & $91.39 \mathrm{mM}$ & $\begin{array}{c}-1.35 \\
\mathrm{Kcal} / \mathrm{mol}\end{array}$ & $\begin{array}{c}-0.07 \\
\mathrm{Kcal} / \mathrm{mol}\end{array}$ & $\begin{array}{c}-1.42 \\
\mathrm{Kcal} / \mathrm{mol}\end{array}$ & 129.097 \\
\hline Invertase+ $+\mathrm{Hgcl}_{2}$ & $\begin{array}{c}-6.93 \\
\mathrm{Kcal} / \mathrm{mol}\end{array}$ & $8.31 \mathrm{mM}$ & $\begin{array}{c}-7.52 \\
\mathrm{Kcal} / \mathrm{mol}\end{array}$ & $\begin{array}{c}-0.02 \\
\mathrm{Kcal} / \mathrm{mol}\end{array}$ & $\begin{array}{c}\mathrm{Kcal} / \mathrm{mol} \\
-7.54\end{array}$ & 587.107 \\
\hline
\end{tabular}

Table 2: Difference in energy of binding between invertase with water and invertase with mercuric chloride as revealed by molecular modelling.

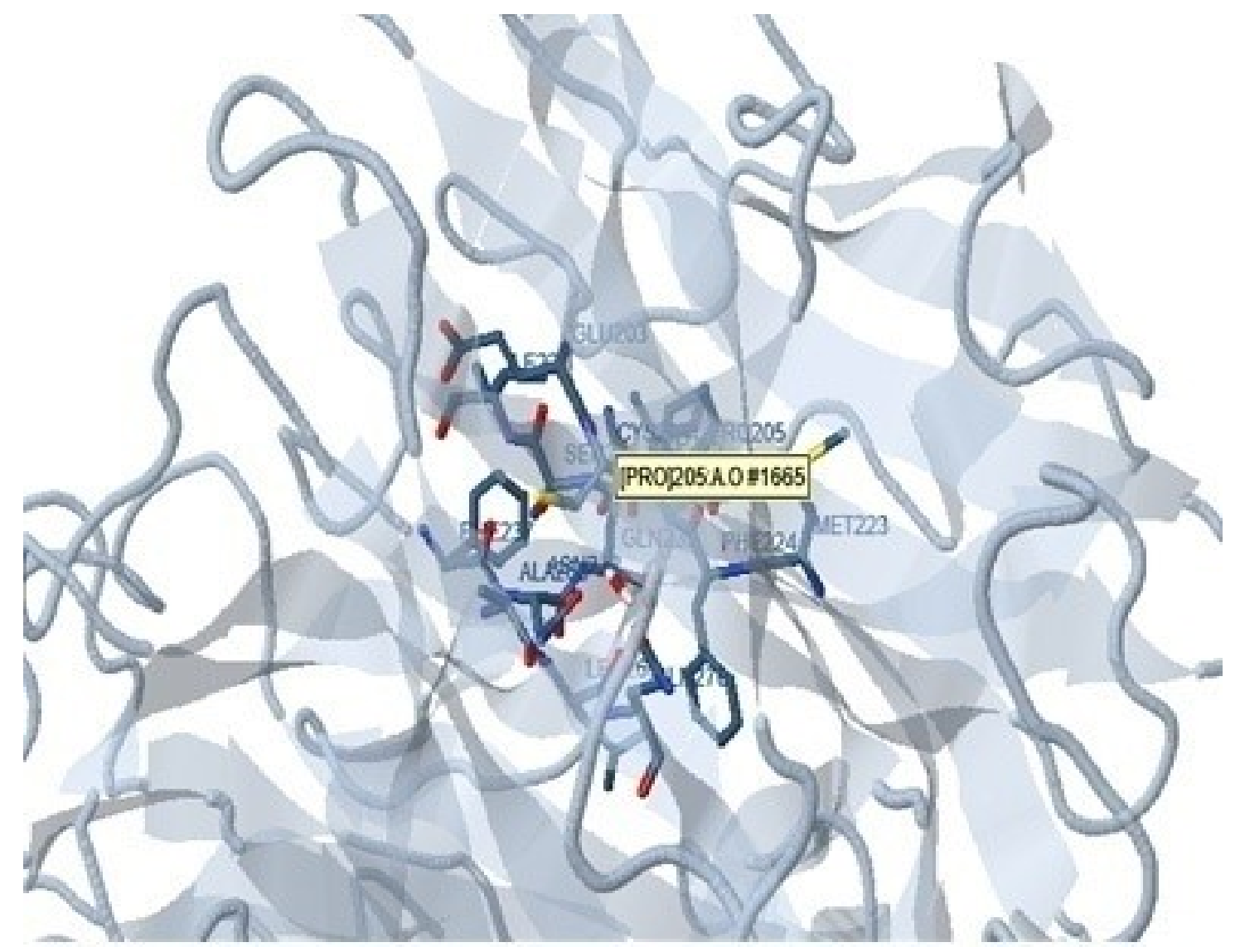

Figure 7. Representative diagram of best docked conformation of invertase-water complex showing the amino acid residues involved in binding with water molecules. Position of amino acids has also been indicated. The box in this figure shows proline at 205 in the side chain of invertase, and oxygen atom no. 1665. 


\section{Fluorescence Spectroscopy}

Fluorescence spectra of invertase $+\mathrm{Hgcl}_{2}$, invertase + Merc cor $200 \mathrm{cH}$, invertase + Merc cor $1000 \mathrm{cH}$, invertase + ethanol, and invertase + water are shown in figure 8 . There is a difference in the peak position and in intensity of fluorescence with different potencies of drug and also the mother tincture of the drug. The mother tincture shows lowest intensity, and ethanol the highest intensity. Merc cor $200 \mathrm{cH}$ occupies the middle position in intensity. Merc $\operatorname{cor} \theta$ shows peak position at $330 \mathrm{~cm}^{-1}$. Merc cor $200 \mathrm{cH}$ shows peak position at $332 \mathrm{~cm}^{-1}$ and all others have their position at $334 \mathrm{~cm}^{-1}$.

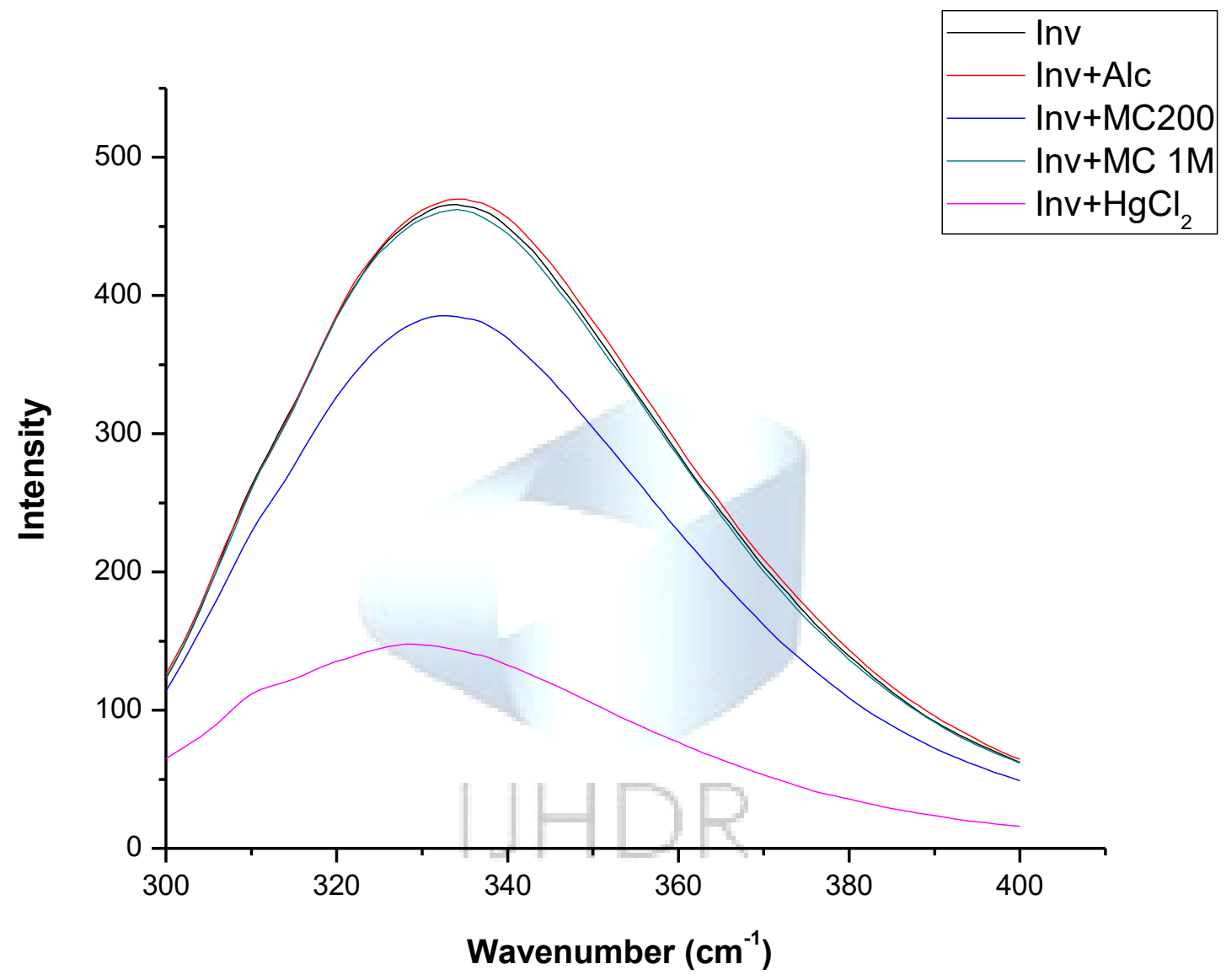

Figure 8: Fluorescence spectra of $4 \mu \mathrm{M}$ invertase mixed with $0.15 \mathrm{M} \mathrm{HgCl}_{2}, M e r c \operatorname{cor} 200 \mathrm{cH}, 1000 \mathrm{cH}$, ethanol and water control in the proportion of 10:1. Ethanol content in ethanol and drug solutions was negligible. Excitation $\lambda$ was $280 \mathrm{~nm}$ and Emission $\lambda 300-400 \mathrm{~nm}$. Note marked variation in intensity with Merc $\operatorname{cor} \theta$ and Merc $\operatorname{cor} 200 \mathrm{cH}$. Merc $\operatorname{cor} \theta$ shows red shift in relation to the control and drug solution

\section{Discussion}

Proteins constitute a very important group of macromolecules in all life forms. They are present on cell membranes which are made up of lipid bilayers. Proteins realize their functions through binding to other molecules including other proteins. Homeopathic drugs are applied on cell membranes either in oral mucosa or on leaves of plants. So the drug molecules interact first with the proteins. The transient protein binding is critical to life and help organisms respond rapidly to a change in metabolic and environmental conditions [19]. In the present study we used the protein, invertase. 
Earlier we tested 3 other potencies like $\alpha$-amylase, serum albumin and insulin with different homeopathic potencies $[20,21,22]$. None of them is a membrane protein. Our aim is to establish first whether homeopathic potencies act on the binding sites of a protein. In our earlier ITC experiments we demonstrated that potencies act as ligands directly binding to proteins. In this study we have shown that homeopathic potencies modify the binding kinetics of a protein with its ligand sucrose. So here the potencies tested act as modulators of the ligand. The binding of $\mathrm{HgCl}_{2}$, its potencies and water to invertase is reversible and non covalent in nature. In case of Merc $\operatorname{cor} \theta$ this binding occurs between $\mathrm{HgCl}_{2}$ molecules and invertase at specific sites. The potencies and water also bind to invertase molecules but at different sites. Proteins have flexible binding pockets which are lined with amino acid residues. Internal motion of proteins designs and determines binding properties. Amino acid residues outside the binding site also influence the properties of binding pockets [23]. Merc $\operatorname{cor} \theta$ and Merc cor $1 \mathrm{M}$ show marked difference from each other in binding constant $(\mathrm{K})$ and heat change, but less difference with respect to $\Delta \mathrm{H}, \Delta \mathrm{S}$ and $\Delta \mathrm{G}$ (Table1). It is known that higher potencies do not always produce therapeutic effect in increasing strength exactly according to their ranks like $6<12<30<200<1 \mathrm{M}$. The present experimental results provide such an indication.

The negative $\Delta \mathrm{G}$ values in both the controls (water/ethanol) and drug solutions indicate spontaneous binding process between the ligand and the protein. All the drug solutions Merc $\operatorname{cor} \theta, 200 \mathrm{cH}$ and $1000 \mathrm{cH}$ show higher negative values of $\Delta \mathrm{G}$ compared to the control (Table 1). This suggests tighter binding induced by the drug solutions, and in this respect Merc cor $1000 \mathrm{cH}$ occupied the top position (TA instrument application note). It is evident from Table 1 that the heat released during the formation of one mole of a product represents $\Delta \mathrm{H}$, the molar variation of enthalpy of reaction between the ligand and protein. The contribution of enthalpy to binding involves increased number of hydrogen bonds with optimal donor-acceptor geometry and distance at the ligand protein interface. In our study the value of $\Delta \mathrm{H}$ was highest with water followed by Merc cor $200 \mathrm{cH}$, Ethanol, Merc cor $1000 \mathrm{cH}$ and Merc $\operatorname{cor} \theta$. Besides Merc $\operatorname{cor} \theta$ all the drugs used are virtually water because Merc cor potencies were diluted with water 1:1000. So this variation in $\Delta \mathrm{H}$ values between the control and drug solutions, can be attributed to variation in the number of hydrogen bonds with water having the highest number of H-bonds. We can assume that drug solutions had lesser H-bonds or more free $\mathrm{OH}$ groups. It may be mentioned here that water serves as both hydrogen donor and acceptor.

Any change in randomness of components in a chemical system is represented by $\Delta \mathrm{S}$. In our study the components were invertase and sucrose. The entropic contribution consists of two primary components: conformational changes in the protein, here invertase, and the release of bound solvent molecules, here water as hydrophobic groups interact. The binding site of a protein is hydrophobic in nature. So the hydrophobic interactions occur between hydrophobic surfaces of the ligand and the protein. In our study $\Delta S$ also follows the same pattern of variation as $\Delta G$ and $\Delta H$ (Table 1 ). In our earlier study we have demonstrated that homeopathic potencies vary from each other with respect to free water molecules [5-7]. The $\mathrm{K}$ value or binding constant shows the affinity of a protein, here invertase for a ligand. Invertase was mixed with drug/control solutions. Our study shows marked variation in $\mathrm{K}$ values, and the order of variation from the highest to the lowest is: Merc cor $\theta>M e r c$ $\operatorname{cor} 200>$ Merc $\operatorname{cor} 1 \mathrm{M}>$ Ethanol>Water. Here Merc $\operatorname{cor} \theta$ shows highest affinity and water the lowest. This variation is caused by the drug solutions which were mixed with the enzyme. The thermodynamic parameters show that Merc $\operatorname{cor} \theta$ and its potencies could bring about marked changes in conformation and hydrogen bonding of the protein. These changes involve different binding sites of the protein. Molecular modeling study also indicates difference in binding sites between Merc $\operatorname{cor} \theta$ and water with respect to binding parameters and amino acids involved in binding. Merc cor potencies are virtually water. The conformational changes in invertase, induced by drug solutions have been further confirmed by the fluorescence study. The drug solutions produced different degrees of quenching in the enzyme (Fig. 8). Conformational selection model explains that 
a protein can interact with structurally different but functionally suitable ligands [24]. HC and ULC of $\mathrm{HgCl}_{2}$ are structurally different and they produce different binding interactions with the enzyme.

\section{Conclusion}

This study shows that potencies of Mercuric Chloride modify binding kinetics between invertase and its ligand sucrose. The potencies here act as modulators of ligand. Potencies are virtually water. Molecular modeling shows that binding sites of Merc $\operatorname{cor} \theta$ and water in invertase are different. So we can assume that a high dose of Merc cor and its potencies act on different binding sites of the enzyme. It may be that this difference may have a relation with the high dose effect and its opposite ultra low dose effect. Drug solutions induce conformational changes in the enzyme leading to exposure of binding sites for the ligand.

\section{References}

[1] Boericke W. 1927 Pocket Mannual of Homeopathic Materia Medica. Indian Edn. Calcutta : Sett Dey, 1976.

[2] Kent J.T. 1911. Homeopathic Materia Medica. Indian Edn. Calcutta: Sett Dey, 1962.

[3] Chakraborty I, Dutta S, Sukul A, Chakravarty R, Sukul NC. Variation in Free and Bound Water Molecules in Different Homeopathic Potencies as Revealed by Their Fourier Transform Infrared Spectroscopy (FTIR). Int J High Dilution Res 2014; 13: 189-196.

[4] Sarkar T, Konar A, Sukul NC, Chakraborty I, Sukul A. Vibrational Spectroscopy Reveals Differences in Homeopathic Potencies in Terms of Hydrogen Bonding and Free Water Molecules. Environ. Ecol. 2016; 34 (1A): 329-333.

[5] Sarkar T, Konar A, Sukul NC, Majumdar D, Singha A, Sukul A. Raman spectroscopy shows difference in drugs at ultra high dilution prepared with stepwise mechanical agitation. Int. J. High Dilution Res. 2016; 15(1): 2-9.

[6] Sarkar T , Konar A, Sukul NC, Sohel Md A, Sengupta A, Sukul A. DSC reveals variation in enthalpy associated with free water molecules in water ethanol solution exposed to x-rays and magnetic field. Clin. Exp. Homeopathy 2017; 4(1): 50-78.

[7] Konar A, Sarkar T, Sukul NC, Singha A, Sukul A. Raman spectroscopy shows differences in extreme dilutions of three drugs with respect to their free $\mathrm{OH}$ groups and hydrogen bond strength. Clin. Exp. homeopathy 2017; 4: 25-35.

[8] Sarkar T, Konar A, Sukul NC, Sukul A. High and ultra low concentrations of Sodium Chloride initiate their action on binding sites of a protein. Environ. Ecol 2018; 36 (IA): 209213.

[9] Sarkar T , Konar A, Sukul NC, Chakraborty I, Sukul A. High and ultra low doses of Mercuric Chloride affect $\alpha$-amylase starch interaction through two different binding sites of the enzyme. Clin. Exp. homeopathy 2017; 4(3): 22-27. 
[10] Sukul NC, Sukul A. High dilution effects: Physical and biochemical basis. Dordrecht: Kluwer Academic publishers, 2004.

[11] Sukul NC, De A, Sinhababu SP. Potentized Mercuric chloride and Mercuric iodide enhance $\alpha$-amylase activity in vitro. Homeopathy 2002; 91: 217-220.

[12] Konar A, Sarkar T, Sukul NC, Sukul A, Chakraborty I. Transfer of the effect of potentized Mercuric chloride on $\alpha$-amylase from one test tube to another through capillary water. Int. J. High Dilution Res 2015; 14(1): 4-11.

[13] The American Homeopathic pharmacopoeia, 1920.

[14] Farrington EA, A Clinical Materia Medica, $5^{\text {th }}$ edn. revised and enlarged by H. Farrington, (Pratap Medical Publishers PVT.LED, New Delhi) 1928: 211

[15] Sukul (nee Chunari) S, Mondal S, Sukul NC. Sepia 200cH in 1:1000 dilution counteracts the effect of salt sterss in Cowpea seedlings but vehicle $90 \%$ ethanol proves ineffective in the same dilution. Int. J. High Dilution Res 2012; 11: 237-240.

[16] Freyer MW, Lewis EA. Isothermal titration calorimetry: Experimental design, Data analysis and probing macromolecule/ligand binding and kinetic interactions. In: Methods in cell biology. Elsevier 2008;84: 79-113.

[17] Balakrishna S, Prabhune AA. Kinetics and thermodynamics of transpeptidation catalysed by Bacillus subtilis gamma glutamyl transferase. IJBB 2017; 54: 109.

[18] Berman HM, Westbrook J, Feng Z, Gilliland G, Bhat TN, Weissig H, Shindyalov IN, Bourne PE. Nucleic Acids Research. 2000; 28: 235-242.

[19] Albert L, Cox MM, Nelson DL. Lehninger Principles of Biochemistry sixth ed., Freeman and company. NewYork 2005.

[20] Sarkar T, Konar A, Sukul NC, Chakraborty I, Sukul A. High and ultra low doses of mercuric chloride affect $\alpha$-amylase starch interaction through two different binding sites of the enzyme. Clin Exp Homeopathy 2017; 4(3): 22-27.

[21] Konar A, Mondal P, Sukul NC, Chakraborty I \& Sukul A, Dilutionof a homeopathic potency with waterdo not alter number of binding sites during their binding interactionwith a protein. Environ. Ecol 2019; 37 (IB): 318-323.

[22] Konar A, Mondal P, Sukul NC, Chakraborty I \& Sukul A. Ultra high dilution of an antidiabetic drug of plant origin act on binding sites of insulin. J Altern Med Res. 2018; 10: 369374.

[23] Stank A, kokh DB, Fuller JC, Wade RC. Protein binding pocket dynamics. Acc. Chem. Res 2016; 49: 809-815. 
[24] Du X, Li Y, Xia YL, Ai SM, Liang J, Sang P, Ji XL, Liu SQ. Insights into protein ligand interactions: mechanisms, models, and methods. Int. J. Mol. Sci 2016: 17.

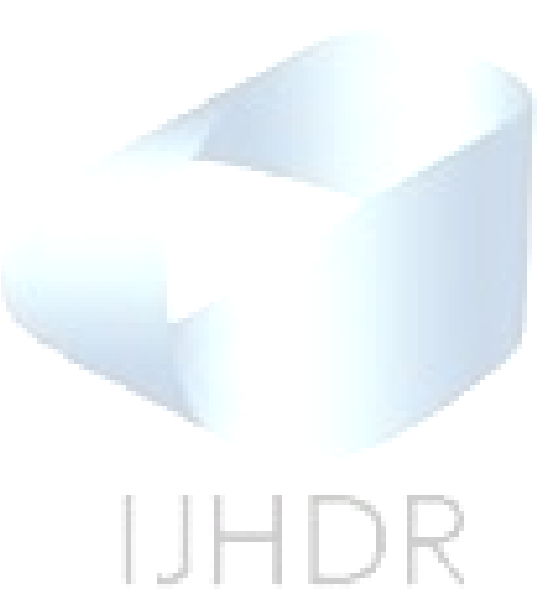

Received: 07 Apr, 2019. Accepted: 27 Aug, 2019.

(c) International Journal of High Dilution Research.

Not for commercial purposes. 